\title{
The Effect of Band-Gap on $\mathrm{TiO}_{2}$ Thin Film Considering Various Parameters
}

\author{
Majedul Haque Mithun, Abu Sayed, Imteaz Rahaman* \\ Department of Electrical and Electronic Engineering, Rajshahi University of Engineering and Technology, \\ Rajshahi, Bangladesh
}

Received 19 May 2021; received in revised form 27 June 2021; accepted 28 June 2021

DOI: https://doi.org/10.46604/peti.2021.7712

\begin{abstract}
The aim of this work is to measure the effect of band-gap on $\mathrm{TiO}_{2}$ thin films by changing tetrabutylorthotitanate (TBOT), diethanolamine (DEA), and temperature. The sol-gel method is experimentally introduced to find out the better band-gap of $\mathrm{TiO}_{2}$ thin films by varying the concentration of TBOT (4 ml to $\left.10 \mathrm{ml}\right)$, DEA (2 ml to $\left.5 \mathrm{ml}\right)$, and temperature $\left(350^{\circ} \mathrm{C}\right.$ to $\left.650^{\circ} \mathrm{C}\right)$. With the help of an ultraviolet-visible spectrophotometer for the wavelength of $300-900 \mathrm{~nm}$, these thin films are characterized concerning optical properties (transmittance spectra, absorbance spectra, direct band-gap, and indirect band-gap). The direct and indirect band-gaps are found $3.38 \mathrm{eV}$ and $3.25 \mathrm{eV}$ respectively, which are close to or within the standard band-gap range of $\mathrm{TiO}_{2}(3.2 \mathrm{eV}$ to $3.35 \mathrm{eV})$ and are found at 8 $\mathrm{ml} \mathrm{TBOT,} 3 \mathrm{ml} \mathrm{DEA}$, and a temperature of $550^{\circ} \mathrm{C}$.
\end{abstract}

Keywords: automatic sol-gel, optical properties, band-gap, $\mathrm{TiO}_{2}$

\section{Introduction}

Titanium dioxide $\left(\mathrm{TiO}_{2}\right)$ is widely used in photocatalytic applications as it provides chemical stability, non-toxicity, and low cost [1-2]. Nowadays, $\mathrm{TiO}_{2}$ is also considered an energy conversion material. It could be electrode materials for lithium-ion batteries [3] embedded in the membrane of polymer electrolyte fuel cells [4]. $\mathrm{TiO}_{2}$ is one of the popular candidates, as its band-gap is quite wide, and therefore only the ultraviolet region of the light could be absorbed [5].

The sample preparation conditions, crystal phase, surface area, size distribution, and porosity [6-7] are mainly responsible for the photocatalytic properties of $\mathrm{TiO}_{2}$. Additionally, the photocatalytic movement of anatase $\mathrm{TiO}_{2}$ is higher than rutile $\mathrm{TiO}_{2}$ because of the fact that the band-gap energy of anatase $(3.23 \mathrm{eV})$ is higher than the rutile $(3.00 \mathrm{eV})$ [8]. However, some methods, namely chemical routes such as sol-gel dip-coating [9] and sol-gel spin-coating [10], consume less energy and do not require expensive equipment.

Many research groups have demonstrated that the nano- $\mathrm{TiO}_{2}$ films prepared from the sol-gel method can make good photoanodes of dye-sensitized solar cells [11] and photo electrocatalytic hydrogen production devices [12]. The structural, electronic, and optical properties of iron $(\mathrm{Fe})$-doped $\mathrm{TiO}_{2}$ thin films by sol-gel technique are investigated, which shows that the increase of illumination intensity causes the increase of photocurrents [13]. The machine learning algorithm is an important criterion to learn types of atoms considering structural geometrical data of anatase $\mathrm{TiO}_{2}$ nanoparticles [14]. A magnetron sputtering technique is used for coating sulfur electrodes into the $\mathrm{TiO}_{2}$ thin film with the variation of deposition times [15]. The Gaussian process regression model is developed for the predictions of anatase $\mathrm{TiO}_{2}$ photocatalysts' energy band gaps depending on the lattice parameters and surface area [16]. The $\mathrm{TiO}_{2}$ thin-film preparation using sol-gel spin coating process is briefly investigated along with optical and material characteristics for future research scope [17]. A Cd-Si co-doped TiO2

* Corresponding author. E-mail address: imteaz.eee.ruet@gmail.com 
hierarchical coating on the surface of a glass slide is fabricated, which exhibits superhydrophobic properties. Besides, the optical band-gap and surface chemical ligands of the prepared thin films are studied [18]. Any change of charge distribution of the crystal unit cells leads to the variation of the single-oscillator parameters [19].

This study serves many purposes to optimize TiO2 thin films. First of all, it fabricates TiO2 thin films by sol-gel method. Characterization of optical properties of $\mathrm{TiO} 2$ thin films by ultraviolet-visible spectrophotometer is another focus of this research work. Measuring the effect of band-gap on $\mathrm{TiO} 2$ thin films by changing various parameters, i.e., tetrabutylorthotitanate (TBOT), diethanolamine (DEA), and temperature, is a major work to fulfill the research goal. Finding out the better band-gap of TiO2 thin films with the concentration of TBOT, DEA, and temperature is the ultimate focus of this study.

\section{Experimental Details}

In this section, the sol-gel transition, sol-gel process, preparation of $\mathrm{TiO}_{2}$ thin films, substrate cleaning, and preparation of precursor solution are briefly described.

\subsection{Sol-gel process}

In this compound method, the "sol" (or arrangement) is gradually developed towards the arrangement of a gel-like diphasic framework containing both the fluid stage and strong stage whose morphologies go from discrete particles to consistent polymer organizations. The arrangement of polymer network includes interfacing the metal habitats with oxo (M-OM) or hydroxo (M-OH-M) spans.

$$
\begin{aligned}
& M-O R+\mathrm{H}_{2} \mathrm{O} \rightarrow \mathrm{M}-\mathrm{OH}+\mathrm{ROH} \\
& M-\mathrm{OH}+\mathrm{HO}-\mathrm{M} \rightarrow \mathrm{M}-\mathrm{O}-\mathrm{M}+\mathrm{H}_{2} \mathrm{O} \\
& M-\mathrm{OR}+\mathrm{HO}-\mathrm{M} \rightarrow \mathrm{M}-\mathrm{O}-\mathrm{M}+\mathrm{ROH}
\end{aligned}
$$

\subsection{Preparation of $\mathrm{TiO}_{2}$ thin film}

$\mathrm{TiO}_{2}$ thin film can be prepared by using four steps: substrate cleaning, precursor solution preparation, substrate dipping and withdrawing, and heat treatment. The whole process is shown in Fig. 1.

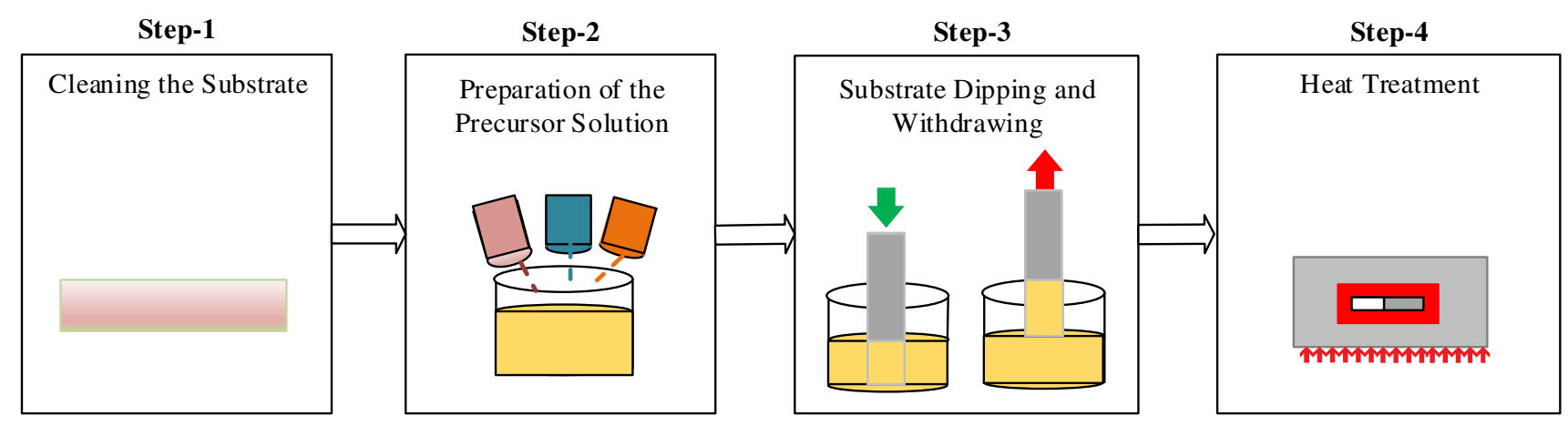

Fig. 1 Different steps of sol-gel process

\subsection{Preparation of precursor solution}

At first, a specific amount of TBOT is dissolved into a specific amount of absolute ethanol to yield a specific concentrated solution, and then it is magnetically stirred for 2 hours. After stirring for $2 \mathrm{~h}$ at room temperature, a mixed solution of water and ethanol in the ratio of 1:10 is added dropwise. The resultant alkoxide solution is stirred at room temperature for hydrolysis reaction for $2 \mathrm{~h}$. Hence, the precursor solution is made through this process. Then, the glass substrate is dipped in and pulled 
back from the solution to make thin layer of $\mathrm{TiO}_{2}$ film on glass substrate. The dipping and withdrawal speed is $2 \mathrm{~mm} / \mathrm{sec}$. The substrates cover with the gel films dried at $600^{\circ} \mathrm{C}$ before calcining at $550^{\circ} \mathrm{C}$ for $1 \mathrm{~h}$. The magnetic stirrer employed in this work is shown in Fig. 2.

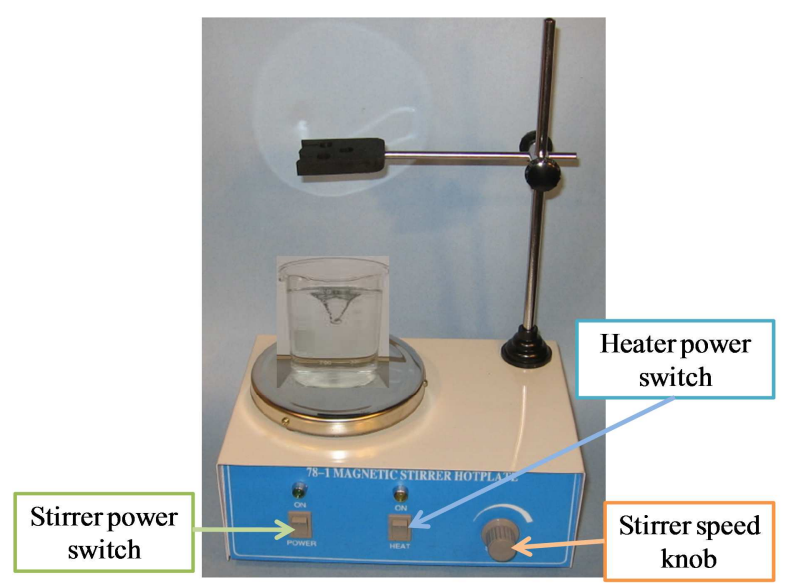

Fig. 2 Magnetic stirrer used for stirring solution

\section{Result Analysis}

The result is analyzed into three parameters. $\mathrm{TiO}_{2}$ film is deposited by TBOT variation, DEA variation, and temperature variation, which is briefly shown in this section. A low-cost dye-sensitized solar cell is fabricated later successfully with the sol-gel derived $\mathrm{TiO}_{2}$ thin film/photoelectrode. To do this chlorophyllin-sodium copper salt dye, carbon counter electrode and KI-based electrolyte are also used. This result shows that the photoelectron conversion efficiency of the $\mathrm{TiO}_{2}$ thin film/photoelectrode, deposited with $1.0 \mathrm{~g}$ of polyethylene glycol (PEG), is the highest among the samples of this investigation. $8 \mathrm{ml}$ TBOT and $3 \mathrm{ml}$ DEA are used to prepare the precursor solution [20]. That is why $8 \mathrm{ml}$ TBOT and $3 \mathrm{ml}$ DEA are used in this research.

\subsection{Deposition of $\mathrm{TiO}_{2}$ film by $\mathrm{TBOT}$ variation}

In this section, firstly, the transmittance and absorbance spectra of thin films for various concentrations of TBOT keeping DEA steady at $3 \mathrm{ml}$ is prepared. Fig. 3(a) shows the optical conveyance spectra of the prepared films. All the films have a sharp cut-off at around $380 \mathrm{~nm}$ wavelength and reach to the top at around $400 \mathrm{~nm}$. The film which has TBOT concentration of $8 \mathrm{ml}$ is close to the standard curve. Corresponding absorbance spectra is shown in Fig. 3(b).

According to Tauc law reliance of assimilation, the co-productive $\alpha$ on photon vitality (hv) can be expressed in Eq. (4).

$$
\alpha h v=A(h v-E g)^{m}
$$

where $m$ is equivalent to $1 / 2$ and 2 for immediate and aberrant changes separately, $\alpha$ is ingestion coefficient, $A$ is edge width boundary, and $\mathrm{h} v$ is photon energy. The equation of $\alpha$ is expressed in Eq. (5).

$$
\alpha=\frac{4 \pi k_{0}}{\lambda}
$$

The transmitted light can be absorbed by the film material. In the fundamental absorption region, the transmission $T$ is given in Eq. (6) [21].

$$
T=A \exp \left(\frac{-4 \pi k_{0} t}{\lambda}\right)
$$


where $k_{0}$ is the extinction coefficient. From Eq. (6), $t$ is film thickness and $\lambda$ is the wavelength of incident light. If $k_{0}<<\mathrm{n}$, then the principle variation of $T$ occurs in the exponential term, and the pre-exponential term $A$ which accounts for reflecting effect is close to unity. In this regard, the equation of $T$ is shown in Eq. 7 [1].

$$
T=\exp (-\alpha \mathrm{t})
$$

Then, from Eq. (7), the absorption coefficient [22] can be expressed as:

$$
\alpha=2.303 \log \left(\frac{100}{T}\right)
$$

Hence, by knowing the value of transmittance $T$, the value of absorption coefficient $\alpha$ can be determined. Again, Eq. (9) describes the photon energy.

$$
E=h v=\frac{h c}{\lambda}=\frac{1240}{\lambda}(\mathrm{ev})
$$

Fig. 3(c) shows the curves of $(\alpha h v)^{2}$ versus photon energy $\mathrm{h} v$ for direct band-gap transitions of $\mathrm{TiO}_{2}$ thin films for different concentrations of TBOT keeping DEA constant at $3 \mathrm{ml}$. It can be shown from Fig. 3 that for $8 \mathrm{ml}$ TBOT the band-gap $(3.28 \mathrm{eV})$ is within the range of the standard band-gap $(3.20-3.35 \mathrm{eV})$. Direct band-gap transitions of $\mathrm{TiO}_{2}$ thin films for different concentration of TBOT keeping DEA constant at $3 \mathrm{ml}$ is shown in Fig. 3(c). It can be shown from the Fig. 3 that for 8 $\mathrm{ml}$ and $10 \mathrm{ml}$ TBOT, it is close to the standard band gap range of $3.20-3.35 \mathrm{eV}$ of $\mathrm{TiO}_{2}$. For $4 \mathrm{ml}$ TBOT, it is within the standard range. However, for $6 \mathrm{ml}$ TBOT, it is very low from the standard mark. Indirect band-gap transitions of $\mathrm{TiO}_{2}$ thin films for different concentration of TBOT keeping DEA constant at $3 \mathrm{ml}$ is shown in Fig. 3(d).

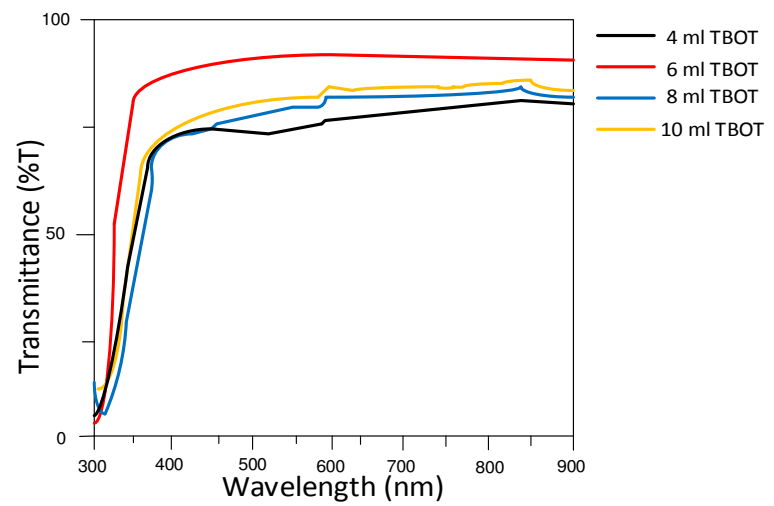

(a) Transmittance spectra

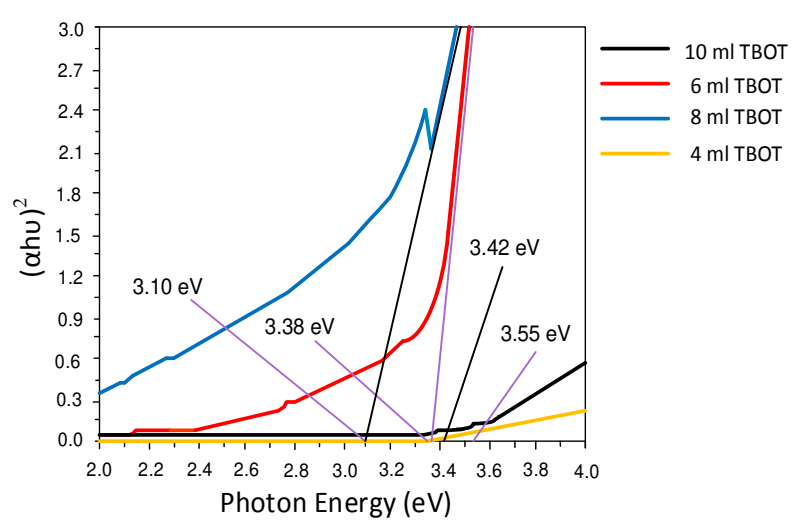

(c) Direct band-gap transition

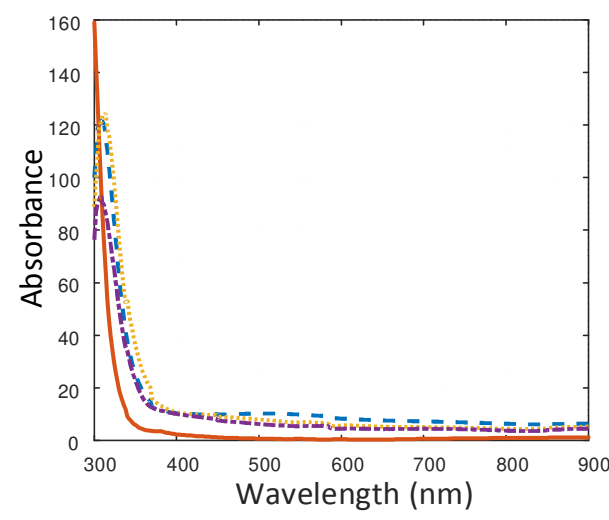

(b) Absorbance spectra

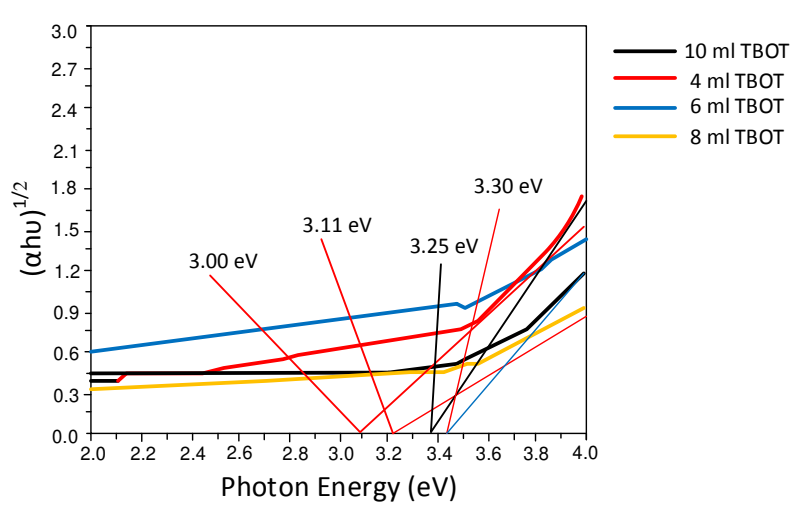

(d) Indirect band-gap transition

Fig. 3 Various parameters of $\mathrm{TiO}_{2}$ thin films for different concentration of TBOT keeping DEA constant at $3 \mathrm{ml}$ 
The variation of TBOT keeping DEA constant at $3 \mathrm{ml}$ is shown in Table 1 . In this table, direct and indirect band-gaps are given. The band-gaps are measured with $4 \mathrm{ml}, 6 \mathrm{ml}, 8 \mathrm{ml}$, and $10 \mathrm{ml}$ TBOT. Here, $8 \mathrm{ml}$ TBOT is highlighted for its better performance.

Table 1 TBOT variation keeping DEA constant at $3 \mathrm{ml}$

\begin{tabular}{|c|c|c|}
\hline Variation & Direct band-gap (eV) & Indirect band-gap (eV) \\
\hline $4 \mathrm{ml} \mathrm{TBOT}$ & 3.58 & 3.28 \\
\hline $6 \mathrm{ml} \mathrm{TBOT}$ & 3.44 & 2.70 \\
\hline $\mathbf{8 ~ m l ~ T B O T ~}$ & $\mathbf{3 . 2 8}$ & $\mathbf{3 . 1 8}$ \\
\hline $10 \mathrm{ml}$ TBOT & 3.49 & 3.11 \\
\hline
\end{tabular}

From Figs. 3(c)-(d) and Table 1, it is clear that both direct and indirect band gap for $8 \mathrm{ml}$ TBOT is close to or within the standard range. Therefore, for further optimization, the concentration of TBOT is fixed at $8 \mathrm{ml}$ in this study.

\subsection{Deposition of $\mathrm{TiO}_{2}$ film by $\mathrm{DEA}$ variation}

From the previous section, this work has the optimized value of TBOT at $8 \mathrm{ml}$. Now, keeping TBOT at $8 \mathrm{ml}$, this section varies DEA. $\mathrm{TiO}_{2}$ films are prepared by DEA variation by sol-gel process so that the surface of prepared films is grown uniformly. It can be clearly understood that the sol-gel derived $\mathrm{TiO}_{2}$ films are visually transparent. First, the transmittance and absorbance spectra of thin films for different concentrations of DEA keeping TBOT constant at $8 \mathrm{ml}$ is shown.

Fig. 4(a) shows the optical transmittance spectra of the prepared films. All the films have a very sharp cut-off at around 380 $\mathrm{nm}$ wavelength and reach to the peak at around $400 \mathrm{~nm}$. The films are highly transparent in the visible range and have low transmittance at the ultraviolet region. It is noted that the average transparency of the sol-gel derived $\mathrm{TiO}_{2}$ films is $81 \%$ in the visible range. The film which has DEA concentration of $3 \mathrm{ml}$ is closer to the standard curve. Corresponding absorbance spectra are shown in Fig. 4(b). Direct band-gap transitions of $\mathrm{TiO}_{2}$ thin films for different concentration of TBOT keeping DEA constant at $3 \mathrm{ml}$ is shown in Fig. 4(c). Indirect band-gap transitions of $\mathrm{TiO}_{2}$ thin films for different concentration of DEA keeping TBOT constant at $8 \mathrm{ml}$ is shown in Fig. 4(d). The variation of DEA keeping TBOT constant at $8 \mathrm{ml}$ is shown in Table 2.

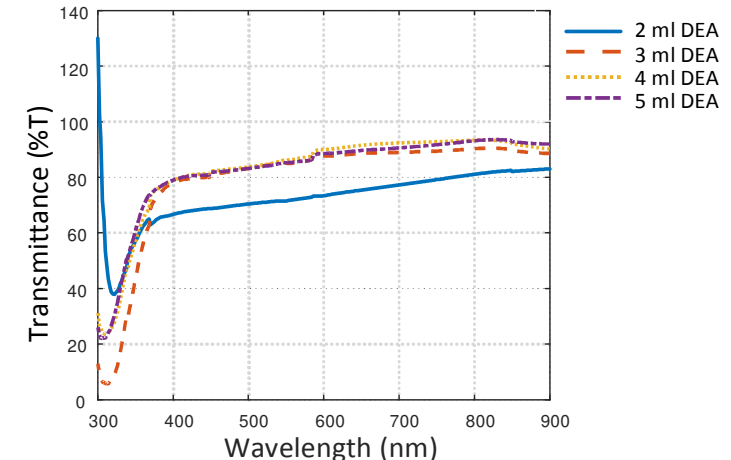

(a) Transmittance spectra

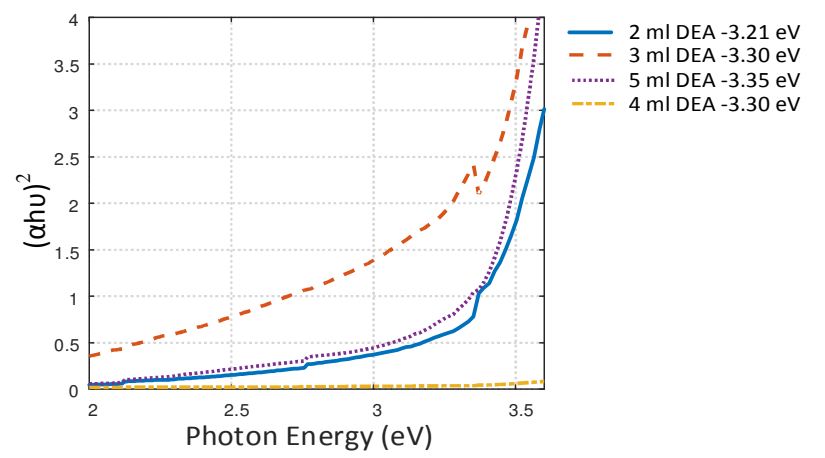

(c) Direct band-gap transition

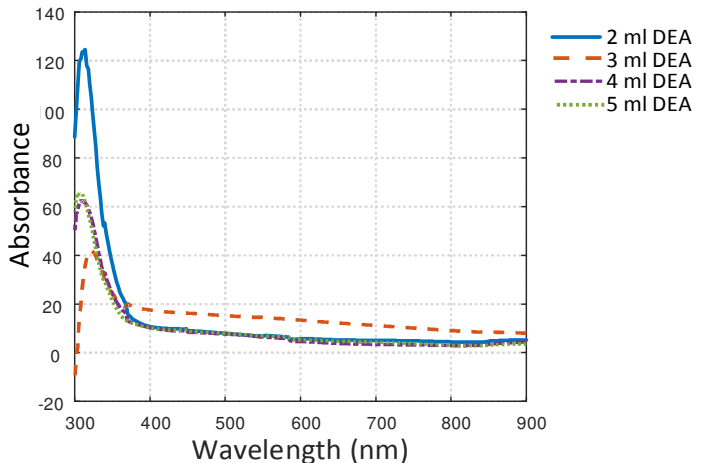

(b) Absorbance spectra

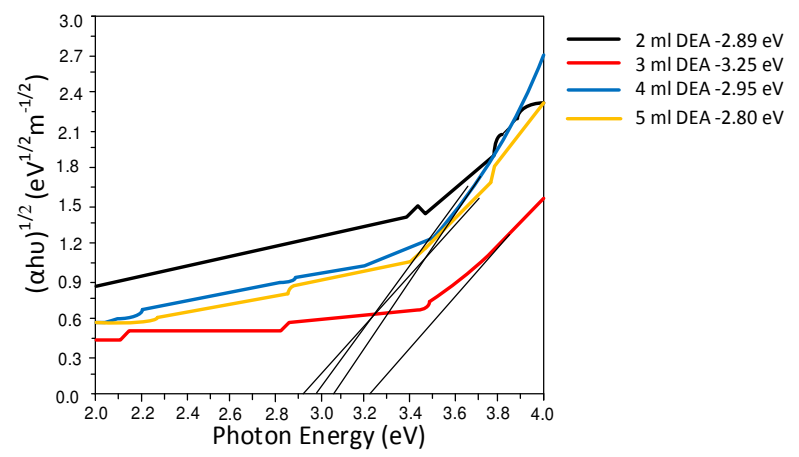

(d) Indirect band-gap transition

Fig. 4 Various parameters of $\mathrm{TiO}_{2}$ thin films for different concentration of DEA keeping TBOT constant at $8 \mathrm{ml}$ 
Table 2 DEA variation keeping TBOT constant at $8 \mathrm{ml}$

\begin{tabular}{|c|c|c|}
\hline Variation & Direct band-gap (eV) & Indirect band-gap (eV) \\
\hline 2 ml DEA & 3.21 & 2.89 \\
\hline 3 ml DEA & $\mathbf{3 . 3 0}$ & $\mathbf{3 . 2 5}$ \\
\hline $4 \mathrm{ml}$ DEA & 3.30 & 2.95 \\
\hline $5 \mathrm{ml}$ DEA & 3.35 & 2.80 \\
\hline
\end{tabular}

From Figs. 4(c)-(d) and Table 2, it is clear that both direct and indirect band gap for 3ml DEA is within the standard range. Therefore, for further optimization, the concentration of DEA is fixed at $3 \mathrm{ml}$ in this study.

\subsection{Deposition of $\mathrm{TiO}_{2}$ film by temperature variation}

The transmittance and absorbance spectra of thin films for temperature variation keeping TBOT and DEA constant at $8 \mathrm{ml}$ and $3 \mathrm{ml}$ respectively are shown. Fig. 5(a) shows the optical transmittance spectra of the prepared films. All the films have a very sharp cut-off at around $380 \mathrm{~nm}$ wavelength and reach to the peak at around $400 \mathrm{~nm}$.

The films are highly transparent in the visible range and have low transmittance at the ultraviolet region. It is noted that the average transparency of the sol-gel derived $\mathrm{TiO}_{2}$ films is $80 \%$ in the visible range. The film which has a temperature of $550^{\circ} \mathrm{C}$ is close to the standard curve. Corresponding absorbance spectra is shown in Fig. 5(b). Direct band-gap transitions of $\mathrm{TiO}_{2}$ thin films for temperature variation keeping TBOT and DEA constant at $8 \mathrm{ml}$ and $3 \mathrm{ml}$ respectively are shown in Fig. 5(c), presenting the curves of $[\mathrm{h}]^{2}$ versus photon energy hv. It can be shown from Fig. 5 that for $550^{\circ} \mathrm{C}$ it is within the standard band-gap range of $3.20-3.35 \mathrm{eV}$ of $\mathrm{TiO}_{2}$. For $650^{\circ} \mathrm{C}$, it is close to the standard range. However, for $350^{\circ} \mathrm{C}$ it is very low from the standard mark. Indirect band-gap transitions of $\mathrm{TiO}_{2}$ thin films for temperature variation keeping TBOT and DEA constant at $8 \mathrm{ml}$ and $3 \mathrm{ml}$ respectively are shown in Fig. 5(d).

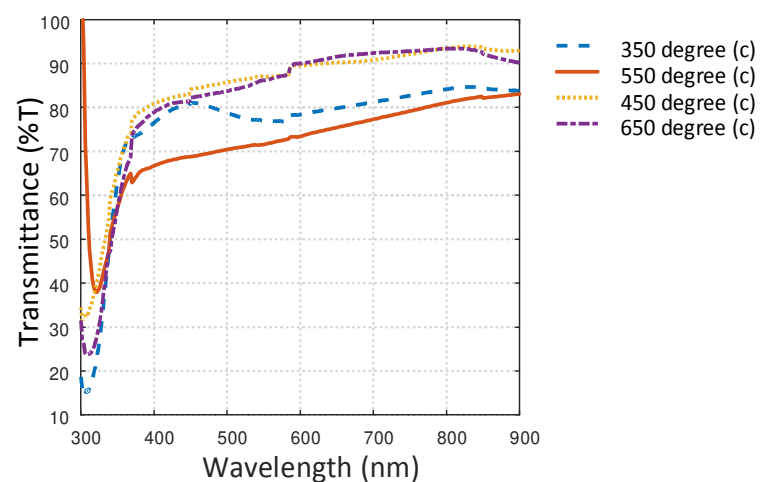

(a) Transmittance spectra

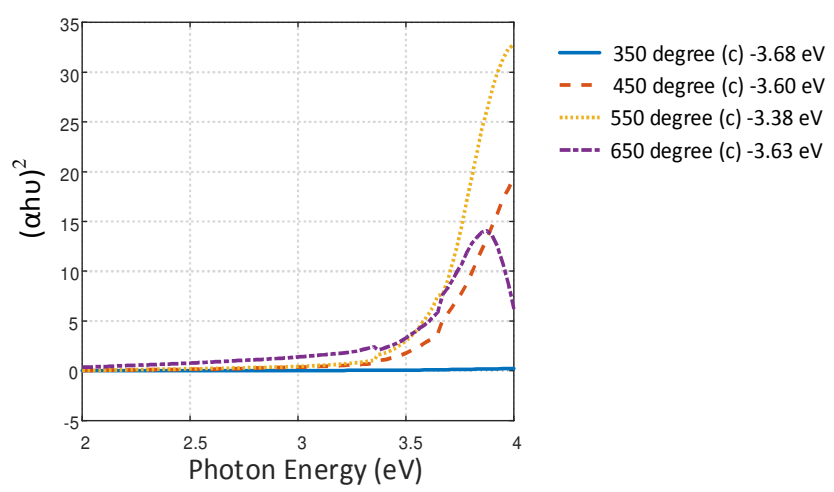

(c) Direct band-gap transition

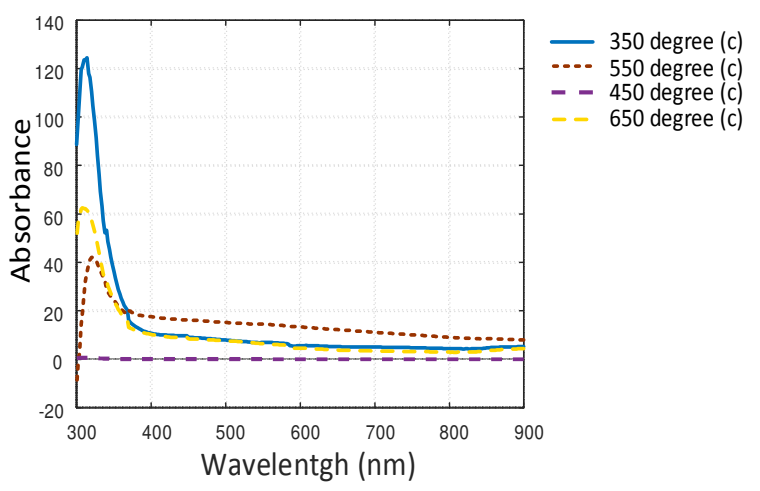

(b) Absorbance spectra

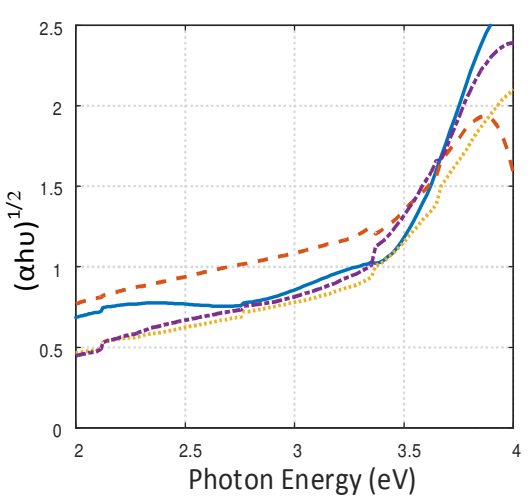

(d) Indirect band-gap transition

Fig. 5 Various parameters of $\mathrm{TiO}_{2}$ thin films for temperature variation keeping TBOT and DEA constant at $8 \mathrm{ml}$ and $3 \mathrm{ml}$ respectively 
Temperature variation is shown in Table 3 keeping DEA and TBOT constant at $3 \mathrm{ml}$ and $8 \mathrm{ml}$ respectively. From Figs. 5(c)-(d) and Table 3, it is clear that both direct and indirect band gap for $550^{\circ} \mathrm{C}$ is close to or within the standard range. Therefore, the optimum temperature is $550^{\circ} \mathrm{C}$ for a better band gap by keeping TBOT and DEA at $8 \mathrm{ml}$ and $3 \mathrm{ml}$ respectively. The direct and indirect band-gaps are found $3.38 \mathrm{eV}$ and $3.25 \mathrm{eV}$ respectively, which are close to or within the standard band-gap range of $\mathrm{TiO}_{2}(3.2 \mathrm{eV}-3.35 \mathrm{eV})$ and are found at $8 \mathrm{ml}$ TBOT, $3 \mathrm{ml} \mathrm{DEA}$, and a temperature of $550^{\circ} \mathrm{C}$. Finally, the whole result is shown in Table 4.

Table 3 Temperature variation keeping DEA and TBOT constant at $3 \mathrm{ml}$ and $8 \mathrm{ml}$ respectively

\begin{tabular}{|c|c|c|}
\hline Variation & Direct band-gap (eV) & Indirect band-gap (eV) \\
\hline $350^{\circ} \mathrm{C}$ & 3.68 & 2.99 \\
\hline $450^{\circ} \mathrm{C}$ & 3.60 & 2.88 \\
\hline $\mathbf{5 5 0}^{\circ} \mathrm{C}$ & $\mathbf{3 . 3 8}$ & $\mathbf{3 . 2 5}$ \\
\hline $650^{\circ} \mathrm{C}$ & 3.63 & 3.19 \\
\hline
\end{tabular}

Table 4 Summary of the whole experiment

\begin{tabular}{|c|c|c|}
\hline \multicolumn{3}{|c|}{ TBOT variation keeping DEA constant at $3 \mathrm{ml}$} \\
\hline Variation & Direct band-gap (eV) & Indirect band-gap (eV) \\
\hline $4 \mathrm{ml} \mathrm{TBOT}$ & 3.58 & 3.28 \\
\hline $6 \mathrm{ml} \mathrm{TBOT}$ & 3.44 & 2.70 \\
\hline $8 \mathrm{ml}$ TBOT & 3.28 & 3.18 \\
\hline $10 \mathrm{ml} \mathrm{TBOT}$ & 3.49 & 3.11 \\
\hline \multicolumn{3}{|c|}{ DEA variation keeping TBOT constant at $8 \mathrm{ml}$} \\
\hline Variation & Direct band-gap (eV) & Indirect band-gap (eV) \\
\hline $2 \mathrm{ml}$ DEA & 3.21 & 2.89 \\
\hline 3 ml DEA & 3.30 & 3.25 \\
\hline $4 \mathrm{ml}$ DEA & 3.30 & 2.95 \\
\hline $5 \mathrm{ml} \mathrm{DEA}$ & 3.35 & 2.80 \\
\hline \multicolumn{3}{|c|}{ Temperature variation keeping DEA and TBOT constant at $3 \mathrm{ml}$ and $8 \mathrm{ml}$ respectivel } \\
\hline Variation & Direct band-gap (eV) & Indirect band-gap $(\mathrm{eV})$ \\
\hline $350^{\circ} \mathrm{C}$ & 3.68 & 2.99 \\
\hline $450^{\circ} \mathrm{C}$ & 3.60 & 2.88 \\
\hline $550^{\circ} \mathrm{C}$ & 3.38 & 3.25 \\
\hline $650^{\circ} \mathrm{C}$ & 3.63 & 3.19 \\
\hline
\end{tabular}

\section{Conclusions}

This study mainly focuses on the measurement of the effect of band-gap on $\mathrm{TiO}_{2}$ thin films by changing TBOT, DEA, and temperature At $550^{\circ} \mathrm{C}$, the band-gap is better than the rest of the combination $\left(350^{\circ} \mathrm{C}, 450^{\circ} \mathrm{C}\right.$, and $\left.650^{\circ} \mathrm{C}\right)$. Therefore, the direct and indirect band-gap are found $3.38 \mathrm{eV}$ and $3.25 \mathrm{eV}$ respectively, which are close to or within the standard band-gap range of $\mathrm{TiO}_{2}$ at $8 \mathrm{ml} \mathrm{TBOT,} 3 \mathrm{ml}$ DEA, and a temperature of $550^{\circ} \mathrm{C}$.

\section{Conflicts of Interest}

The authors declare no conflict of interest.

\section{References}

[1] A. Velasco-Hernández, R. A. Esparza-Muñoz, F. J. de Moure-Flores, J. Santos-Cruz, and S. A. Mayén-Hernández, "Synthesis and Characterization of Graphene Oxide- $\mathrm{TiO}_{2}$ Thin Films by Sol-Gel for Photocatalytic Applications," Materials Science in Semiconductor Processing, vol. 114, 105082, August 2020.

[2] S. Salaeh, M. Kovacic, D. Kosir, H. Kusic, U. L. Stangar, D. D. Dionysiou, et al., "Reuse of TiO ${ }_{2}$-Based Catalyst for Solar Driven Water Treatment; Thermal and Chemical Reactivation," Journal of Photochemistry and Photobiology A: Chemistry, vol. 333, pp. 117-129, January 2017. 
[3] T. Hasegawa, A. B. Beleke, and M. Mizuhata, "Membrane Modification by Liquid Phase Deposition Using Small Amount of $\mathrm{TiO}_{2}$ for High Temperature Operation of Polymer Electrolyte Fuel Cells," Journal of Power Sources, vol. 233, pp. 148-156, July 2013.

[4] D. Dambournet, I. Belharouak, and K. Amine, "Tailored Preparation Methods of $\mathrm{TiO}_{2}$ Anatase, Rutile, Brookite: Mechanism of Formation and Electrochemical Properties," Chemistry of Materials, vol. 22, no. 3, pp. 1173-1179, February 2010.

[5] Y. Liao, W. Que, Q. Jia, Y. He, J. Zhang, and P. Zhong, "Controllable Synthesis of Brookite/Anatase/Rutile TiO Nanocomposites and Single-Crystalline Rutile Nanorods Array,” Journal of Materials Chemistry, vol. 22, no. 16, pp. 7937-7944, April 2012.

[6] T. Noguchi, A. Fujishima, P. Sawunyama, and K. Hashimoto, "Photocatalytic Degradation of Gaseous Formaldehyde Using $\mathrm{TiO}_{2}$ Film,” Environmental Science and Technology, vol. 32, no. 23, pp. 3831-3833, December 1998.

[7] D. H. Kim, H. S. Hong, S. J. Kim, J. S. Song, and K. S. Lee, "Photocatalytic Behaviors and Structural Characterization of Nanocrystalline Fe-Doped $\mathrm{TiO}_{2}$ Synthesized by Mechanical Alloying," Journal of Alloys and Compounds, vol. 375 , no. 1-2, pp. 259-264, July 2004.

[8] W. T. Chiou, W. Y. Wu, and J. M. Ting, “Growth of Single Crystal ZnO Nanowires Using Sputter Deposition,” Diamond and Related Materials, vol. 12, no. 10-11, pp. 1841-1844, October-November 2003.

[9] W. G. Lee, S. I. Woo, J. C. Kim, S. H. Choi, and K. H. Oh, "Preparation and Properties of Amorphous TiO 2 Thin Films by Plasma Enhanced Chemical Vapor Deposition,” Thin Solid Films, vol. 237, no. 1-2, pp. 105-111, January 1994.

[10] M. Sreemany and S. Sen, "Influence of Calcination Ambient and Film Thickness on the Optical and Structural Properties of Sol-Gel $\mathrm{TiO}_{2}$ Thin Films," Materials Research Bulletin, vol. 42, no. 1, pp. 177-189, January 2007.

[11] P. R. Mishra, P. K. Shukla, A. K. Singh, and O. N. Srivastava, "Investigation and Optimization of Nanostructured TiO 2 Photoelectrode in Regard to Hydrogen Production through Photoelectrochemical Process," International Journal of Hydrogen Energy, vol. 28, no. 10, pp. 1089-1094, October 2003.

[12] J. Jiu, S. Isoda, M. Adachi, and F. Wang, "Preparation of $\mathrm{TiO}_{2}$ Nanocrystalline with 3-5 nm and Application for Dye-Sensitized Solar Cell,” Journal of Photochemistry and Photobiology A: Chemistry, vol. 189, no. 2-3, pp. 314-321, June 2007.

[13] F. Kara, M. Kurban, and B. Coşkun, "Evaluation of Electronic Transport and Optical Response of Two-Dimensional Fe-Doped $\mathrm{TiO}_{2}$ Thin Films for Photodetector Applications,” Optik, vol. 210, 164605, May 2020.

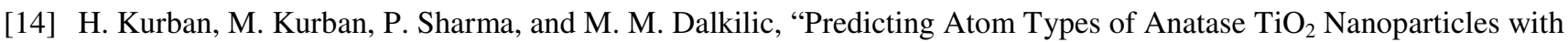
Machine Learning,” Key Engineering Materials, vol. 880, pp. 89-94, 2021.

[15] T. Zerrin, M. Kurban, M. M. Dickson, M. Ozkan, and C. S. Ozkan, "Suppression of the Shuttle Effect in Li-S Batteries via Magnetron Sputtered $\mathrm{TiO}_{2}$ Thin Film at the Electrode-Electrolyte Interface,” ACS Applied Energy Materials, vol. 3, no. 2, pp. 1515-1529, February 2020.

[16] Y. Zhang and X. Xu, "Machine Learning Band Gaps of Doped-TiO ${ }_{2}$ Photocatalysts from Structural and Morphological Parameters," ACS Omega, vol. 5, no. 25, pp. 15344-15352, June 2020.

[17] A. Deyasi, P. Debnath, A. K. Datta, and S. Bhattacharyya, Photonics, Plasmonics, and Information Optics: Research and Technological Advances, Boca Raton: CRC Press, 2021.

[18] S. N. K. Abad, N. N. Ilkhechi, M. Adel, and M. Mozammel, "Hierarchical Architecture of a Superhydrophobic Cd-Si Co-Doped $\mathrm{TiO}_{2}$ Thin Film,” Applied Surface Science, vol. 533, 147495, December 2020.

[19] A. Amini, M. S. Zakerhamidi, and S. Khorram, "Changes of the $\mathrm{TiO}_{2}$ Thin Film Electro-Optical Properties in the Ar and $\mathrm{N}_{2}$ Glow Discharge Plasma Due to Effects of the Electric Field in Plasma's Sheath," Physica B: Condensed Matter, vol. 612, 412820, July 2021.

[20] M. F. Hossain, S. Biswas, T. Takahashi, Y. Kubota, and A. Fujishima, "Effect of Structure and Surface Morphology of Sol-Gel Derived $\mathrm{TiO}_{2}$ Photoelectrode on the Performance of Dye-Sensitized Solar Cells," Journal of Vacuum Science and Technology A: Vacuum, Surfaces, and Films, vol. 26, no. 4, pp. 1007-1011, July 2008.

[21] G. Liu, C. Han, M. Pelaez, D. Zhu, S. Liao, V. Likodimos, et al., "Enhanced Visible Light Photocatalytic Activity of CN-Codoped $\mathrm{TiO}_{2}$ Films for the Degradation of Microcystin-LR,” Journal of Molecular Catalysis A: Chemical, vol. 372 , pp. 58-65, June 2013.

[22] A. Chen, W. F. Chen, T. Majidi, B. Pudadera, A. Atanacio, M. Manohar, et al., "Mo-Doped, Cr-Doped, and Mo-Cr Codoped $\mathrm{TiO}_{2}$ Thin-Film Photocatalysts by Comparative Sol-Gel Spin Coating and Ion Implantation," International Journal of Hydrogen Energy, vol. 46, no. 24, pp. 12961-12980, April 2021.

Copyright $($ by the authors. Licensee TAETI, Taiwan. This article is an open access article distributed under the terms and conditions of the Creative Commons Attribution (CC BY-NC) license (https://creativecommons.org/licenses/by-nc/4.0/). 